IZA DP No. 4448

An Explanation for the Lower Payoff to Schooling for Immigrants in the Canadian Labour Market

Barry R. Chiswick

Paul W. Miller

September 2009 


\title{
An Explanation for the Lower Payoff to Schooling for Immigrants in the Canadian Labour Market
}

\author{
Barry R. Chiswick \\ University of Illinois at Chicago \\ and IZA \\ Paul W. Miller \\ University of Western Australia \\ and IZA
}

\section{Discussion Paper No. 4448 \\ September 2009}

\author{
IZA \\ P.O. Box 7240 \\ 53072 Bonn \\ Germany \\ Phone: +49-228-3894-0 \\ Fax: +49-228-3894-180 \\ E-mail: iza@iza.org
}

\begin{abstract}
Any opinions expressed here are those of the author(s) and not those of IZA. Research published in this series may include views on policy, but the institute itself takes no institutional policy positions.

The Institute for the Study of Labor (IZA) in Bonn is a local and virtual international research center and a place of communication between science, politics and business. IZA is an independent nonprofit organization supported by Deutsche Post Foundation. The center is associated with the University of Bonn and offers a stimulating research environment through its international network, workshops and conferences, data service, project support, research visits and doctoral program. IZA engages in (i) original and internationally competitive research in all fields of labor economics, (ii) development of policy concepts, and (iii) dissemination of research results and concepts to the interested public.
\end{abstract}

IZA Discussion Papers often represent preliminary work and are circulated to encourage discussion. Citation of such a paper should account for its provisional character. A revised version may be available directly from the author. 


\section{ABSTRACT}

\section{An Explanation for the Lower Payoff to Schooling for Immigrants in the Canadian Labour Market ${ }^{*}$}

This paper examines the difference between the payoffs to schooling for immigrants and the native born in Canada, using 2001 Census data. Analyses are presented for males and females. Comparisons are offered with findings for the US. The paper uses the Overeducation/Required education/Undereducation framework (Hartog, 2000) and a decomposition developed by Chiswick and Miller (2008). This decomposition links overeducation to the less-than-perfect international transferability of immigrants' human capital, and under-education to favourable selection in immigration. The results show that immigrants have a lower payoff to schooling because of the different effects under-education and over-education have on their earnings. The effects of under-education, or selection in immigration, are, however, twice as large as the effects of over-education, or limited international transferability of human capital. Favourable selection in immigration appears to be less important in Canada than in the US, where it predominates among the least educated.

JEL Classification: I21, J24, J31, J61, F22

Keywords: immigrants, skill, schooling, earnings, rates of return, Canada

Corresponding author:

Barry R. Chiswick

Department of Economics

University of Illinois at Chicago

601 S. Morgan Street

Chicago, IL 60607-7121

USA

E-mail: brchis@uic.edu

\footnotetext{
* We thank Derby Voon for research assistance. Miller acknowledges financial assistance from the Australian Research Council.
} 


\section{AN EXPLANATION FOR THE LOWER PAYOFF TO SCHOOLING FOR IMMIGRANTS IN THE CANADIAN LABOUR MARKET}

\section{INTRODUCTION}

Studies of immigrant earnings in Canada have established a number of robust findings (Abbott and Beach, 1993; Baker and Benjamin, 1994; Ferrer and Riddell, 2008). Recently arrived immigrants earn less than comparable native-born workers, though this earnings gap diminishes with duration of residence in Canada. There is a positive relationship between the growth in post-arrival earnings and the earnings disadvantage in the immediate post-arrival period. And the returns to education among the foreign born are less than the returns to education for the native born. This latter empirical regularity is the focus of the current study.

A cursory review of the literature shows that the gap in the returns to education for immigrants and the native born is substantial. Baker and Benjamin (1994), for example, reported that the partial effect of years of schooling on earnings was 7.3 percent for nativeborn males and 4.8 percent for male immigrants in 1971, 6.6 percent and 4.4 percent, respectively, for these groups in 1981, and 7.6 percent and 4.9 percent, respectively, for the two groups in 1986. $\quad$ More recently, Ferrer and Riddell (2008), using data from the 1981, 1986, 1991, 1996 and 2001 Censuses, report a payoff to education of 5.3 percent for nativeborn males, 4.6 percent for their foreign-born counterparts who arrived in Canada before they turned 20 years of age, and 3.8 percent for foreign-born males who arrived at age 20 or later. Ferrer and Riddell's (2008) analyses for females revealed a similar pattern, although the payoff to schooling for native-born females, at 8.2 percent, was much higher than that for native-born males (5.3 percent), and the absolute difference between the payoff to education

\footnotetext{
${ }^{1}$ Abbott and Beach (1993) report a 20 percent lower payoff to schooling for immigrants than for the native born in their study of males based on the 1973 Job Mobility Survey, though this difference was not statistically significant.
} 
for female immigrants and their native-born counterparts was greater than in the analyses for males.

Two major factors have been the focus in the discussion of these immigrant-native born earnings and schooling payoff differentials. These are the less-than-perfect international transferability of human capital acquired before immigration, and the selection processes, either by immigration authorities or by the immigrants themselves (i.e., self-selection), that might result in immigrants having a different set of unobservable characteristics to those of the native born (Chiswick, 1978).

At first glance, it would seem that of these two issues, the one that will be of most importance when considering the relatively low payoff to schooling among the foreign born is the less-than-perfect international transferability of skills acquired abroad. Years of schooling acquired in a foreign country, where the curriculum may differ from that in Canadian schools, where the instruction may be in a language other than English or French, and where the school culture may differ from that in Canadian schools, may simply not be equivalent to years of schooling acquired in Canada, in terms of actual labour market productivity or employer perceptions. As a result, foreign schooling attracts a lower return in Canada than schooling acquired in the host country.

Chiswick and Miller (2008) developed a method to assess the contributions of the less-than-perfect international transferability of human capital and selection in migration to the lower payoff to schooling for the foreign born. This method is based on the assumption that the less-than-perfect international transferability of human capital will impact more on the highly educated, and self-selection in immigration will be more intense among the lesswell educated (see Chiswick, 1999). ${ }^{2}$ It involves the estimation of the Over-

\footnotetext{
${ }^{2}$ To simplify the argument, the issue of the transferability of skills is minimal for those with few skills, while the ratio of out of pocket costs of migration to foregone earnings is higher for the less educated, thereby encouraging a higher propensity for favourable selectivity.
} 
education/Required education/Under-education (ORU) earnings equation of Hartog (2000) for the foreign born and the native born, and the use of the estimates to predict earnings for the foreign born at each level of schooling. These predictions are obtained under alternatives that involve the replacement of estimates and values of regressors for the foreign born with corresponding values from the native-born sample. When applied to data from the 2000 US Census, Chiswick and Miller (2008) show that the greater part of the much lower payoff to schooling in the US for the foreign born (payoff of 5.3 per cent) than for the native born (payoff of 10.6 percent) was due to factors that appear to be associated with favourable selfselection in immigration, with the issue of skill transferability playing a lesser role.

This paper applies the Chiswick and Miller (2008) decomposition to data from the 2001 Census of Canada. This application will inform on whether there are similarities in the way immigrant schooling is rewarded in Canada and the US. The analyses also provide an opportunity to examine whether there is path dependence in the decomposition. Path dependence may arise in this decomposition where the findings are sensitive to the order in which the substitution of coefficients and regressors of the native born for coefficients and regressors of immigrants is undertaken. The decompositions are also undertaken for various age at arrival groups to reflect the concerns of Schaafsma and Sweetman (2001) and Ferrer and Riddell (2008), among others, that the outcomes of immigrants who arrive as children, and hence undertake some education in Canada, will differ from the outcomes of immigrants who moved to Canada during their adult years. Finally, the decomposition is also conducted for females, which, given Ferrer and Riddell's (2008) findings of a larger gap between the payoffs to schooling for immigrants and the native born among females than among males, should be an important addition to the literature. ${ }^{3}$

\footnotetext{
${ }^{3}$ We also take the opportunity to, in passing, offer comments on the reason for the higher payoff to schooling for females than for males within each birthplace group (see Ferrer and Riddell, 2008).
} 
The paper is structured as follows. Section II provides a brief overview of the overeducation/under-education methodology and of the recent Chiswick and Miller (2008) decomposition. Section III introduces the data, and discusses the sample exclusions. The regression and decomposition results are presented in Section IV, and this is followed in Section V by comparisons with findings for the US. Section VI contains a summary and conclusion.

\section{THE CHISWICK-MILLER DECOMPOSITION}

The starting point for the approach outlined in Chiswick and Miller (2008) is the ORU specification of the earnings equation (Hartog, 2000). In this model the dependent variable is the natural logarithm of earnings $\left(\ln Y_{i}\right)$ and the variable for actual years of education that is used in the conventional human capital earnings equation is decomposed into three terms, a term for years of over- or surplus education, a term for years of required education, and a term for years of under-education. ${ }^{4}$ The terms for years of over- and under-education are measured relative to the central tendency for education in the respondent's occupation. For simplicity, occupation is treated as exogenous. Specifically,

$$
\ln Y_{i}=\alpha_{0}+\alpha_{1} \text { Over_Educ }_{i}+\alpha_{2} \text { Req_Educ }_{i}+\alpha_{3} \text { Under_Educ }_{i}+\ldots+u_{i}
$$

where

$$
\begin{aligned}
& \text { Over_Educ = years of surplus or over-education, } \\
& \text { Req_Educ = the usual or reference years of education, } \\
& \text { Under_Educ = years of deficit or under-education, }
\end{aligned}
$$

\footnotetext{
${ }^{4}$ In the immigration literature, over-education or surplus education is often referred to as the non-recognition of foreign educational credentials. The central tendency of the educational attainment in an occupation is variously referred to in the ORU literature as the "usual", "reference" or "required" level of education. As there is no standard terminology in the ORU literature, these terms are used here as well.
} 
and the actual years of education equals Over_Educ + Req_Educ - Under_Educ. Note that for each individual, "Over_Educ" and "Under_Educ" cannot both be positive. ${ }^{5}$ Either one or both must be zero. Equation (1) will also contain other variables generally included in earnings functions, such as years of potential labour market experience, marital status, official language skills, location, and, among the foreign born, duration of residence in Canada.

Chiswick and Miller use estimates of equation (1) for the foreign born to predict earnings for each immigrant at a particular level of schooling. Hence:

$$
\begin{gathered}
\widehat{\operatorname{lnY}}=\hat{\alpha}_{0}+\hat{\alpha}_{1} \text { Over_Educ }{ }^{\mathrm{FB}}+\hat{\alpha}_{2}^{\mathrm{FB}} \text { Req_Educ }{ }^{\mathrm{FB}}+\hat{\alpha}_{3}{ }_{3}^{\mathrm{BB}} \text { Under_Educ }^{\mathrm{FB}}+\ldots \forall \text { immigrants } \\
\text { at level of schooling level “ } \mathrm{j} ", \quad \mathrm{j}=1, \ldots, \mathrm{J},
\end{gathered}
$$

where $\mathrm{J}$ is the number of schooling categories.

The predictions obtained for each level of schooling were then averaged, and these averages regressed on the level of schooling. In this supplementary simple regression, each observation was weighted by the number of immigrants with the particular level of schooling $\left(\mathrm{w}_{\mathrm{j}}\right)$. That is:

$$
\widehat{\widehat{\operatorname{lnY}}}_{\mathrm{j} \mathrm{w}_{\mathrm{j}}}=\beta_{0} \mathrm{w}_{\mathrm{j}}+\beta_{1} \mathrm{EDUC}_{\mathrm{j}} \mathrm{w}_{\mathrm{j}}+v_{\mathrm{j}} \mathrm{w}_{\mathrm{j}} \text {, where } \mathrm{w}_{\mathrm{j}} \text { are the weights. }
$$

$\widehat{\beta}_{1}$ in this weighted simple regression is an estimate of the payoff to schooling for the foreign born, formed from the means of the predictions of earnings, ceteris paribus, for each schooling category and the associated years of schooling.

In the second step, the estimated earnings effects from the ORU variables for the native born were used to predict earnings for the foreign born. Specifically, the predictions are:

\footnotetext{
${ }^{5}$ The standard equation, $\ln Y_{i}=\beta_{0}+\beta_{1}$ Actual Educ $_{i}+\ldots+v_{i}$, forces $\alpha_{1}=\alpha_{2}=\left|\alpha_{3}\right|$. As this condition does not hold, the ORU specification results in a higher R-squared and $\alpha_{2}>\beta_{1}$.
} 


$$
\begin{gathered}
\widehat{\operatorname{lnY}}=\hat{\alpha}_{0}{ }^{\mathrm{FB}}+\widehat{\alpha}_{1}^{\mathrm{NB}} \text { Over_Educ }{ }^{\mathrm{FB}}+\widehat{\alpha}_{2}^{\mathrm{NB}} \text { Req_Educ }{ }^{\mathrm{FB}}+\widehat{\alpha}_{3}{ }^{\mathrm{NB}} \text { Under_Educ }^{\mathrm{FB}}+\ldots \forall \text { immigrants } \\
\text { at level of schooling level “ } \mathrm{j} ", \quad \mathrm{j}=1, \ldots, \mathrm{J} .
\end{gathered}
$$

The predictions obtained from (4) were then related to the years of schooling in the weighted simple regression outlined in equation (3). $\widehat{\beta}_{1}$ in this second supplementary regression is the payoff to schooling for the foreign born under the assumption that the payoffs to over-education, required education and under-education are the same for immigrants and the native born. Comparison of this payoff with that obtained using the predictions of equation (2) shows the contribution of the differences in the estimated effects of the ORU variables for the two birthplace groups to the conventional estimate of the payoff to schooling. The predictions in equation (4) can also be obtained replacing one estimated coefficient at a time, in order to identify the estimated coefficients that have the greatest impact.

In the third step, the ORU variables for the foreign born were replaced using the sample averages, conditional upon the particular level of schooling " $\mathrm{j}$ ”, for the native born. That is,

$$
\begin{gathered}
\widehat{\operatorname{lnY}}=\hat{\alpha}_{0}+\hat{\alpha}_{1}^{\mathrm{NB}} \overline{\text { Over_Educ }}^{\mathrm{NB}}+\hat{\alpha}_{2}^{\mathrm{NB}} \overline{\mathbf{R e q} E \text { Educ }}^{\mathrm{NB}}+\hat{\alpha}_{3}^{\mathrm{NB}} \overline{\text { Under_Educ }}^{\mathrm{NB}}+\ldots \forall \text { immigrants } \\
\text { at level of schooling level “ } \mathrm{j} ", \quad \mathrm{j}=1, \ldots, \mathrm{J} .
\end{gathered}
$$

Again, the averages of the predictions at each level of schooling are regressed on the years of schooling via the weighted simple regression in equation (3). $\widehat{\beta}_{1}$ in this third supplementary regression is the estimate of the payoff to schooling for the foreign born under the twin assumptions that the payoffs to the ORU variables for immigrants are the same as for the native born and the mean values of these variables for immigrants are the same as for the native born. This simulated payoff to schooling can be compared to that obtained in the previous step to show the incremental contribution of differences in values of the ORU 
variables for immigrants and the native born to the payoff to schooling obtained by immigrants. Similar to the procedure followed in relation to the predictions obtained from equation (2), the predictions in equation (5) can be obtained replacing the values of the regressors for one ORU variable at a time to identify the relative contributions that these make.

The final step in the Chiswick and Miller (2008) procedure involves using the number of the native born at each level of schooling for the weighting variable in the supplementary simple weighted regression depicted in (3). Following this change, the $\widehat{\beta}_{1}$ obtained from the simple regression will be an estimate of the payoff to schooling for the native born.

Thus, the sequence of substitutions outlined above progressively move us from the payoff to schooling for the foreign born to the payoff to schooling for the native born. The order in which the substitutions are undertaken (i.e., whether those in equation (5) are undertaken prior to those in equation (4)) can be changed to assess the importance of path dependence. Similarly, the complete set of substitutions for the over-education, required education and under-education components of schooling may be undertaken sequentially, so that only the coefficients and means for over-education (or required education or undereducation) are replaced first, and then this is followed by the replacement of the coefficients and means for a further variable in the ORU specification of the earnings equation.

Table 1 illustrates the approach using one of the sets of findings from Chiswick and Miller (2008). 


\section{Table 1}

Implied Payoffs to Schooling, Adjusting for Over- Required- and Under-Education, United States, 2000

Native-born males $\underline{\text { UUU\% Payoff }}$ Foreign-born males - no adjustment

(a) assuming same earnings effects to the ORU variables as for native-born males

(b) as for (a) but also same levels of ORU variables within each schooling category as for native-born males

(c) as for (b) but also assuming same distribution across schooling categories for foreign-born males as for nativeborn males

Source: Chiswick and Miller (2008, Table 6).

In Table 1 the payoff to schooling for native-born males in the US in 2000 Census data computed using the weighted simple regression outlined in equation (3) is 10.5 percent, and that for foreign-born males is 5.3 percent. Thus there is a gap in the payoffs to schooling for native-born and foreign-born males of 5.2 percentage points. Standardisation for the earnings effects of the ORU variables closes this gap by 3.2 percentage points (8.5-5.3). Standardisation for the mean values of the ORU variables closes the gap by only 0.1 percentage point (8.6-8.5). Finally, standardisation for the distribution of the birthplace groups across schooling categories accounts for the remaining 1.9 percentage points. This latter standardisation is important because the foreign born in the US, particularly immigrants from Mexico, are disproportionately represented in low-schooling categories where undereducation has the effect of reducing the conventionally estimated payoff to schooling because of the favourable selectivity in migration.

Chiswick and Miller (2008) repeated these analyses focusing only on the effects of under-education. The findings were broadly in line with those reported in Table 1, suggesting that under-education is a more important phenomenon than is over-education 
when considering the lower payoff to schooling for immigrants. ${ }^{6}$ Thus Chiswick and Miller (2008, p.1331) conclude:

It is quite clear, therefore, that almost all the gap between the payoff to schooling for the foreign born and the native born is due to the earnings effects associated with under-education, and the different distributions of the two birthplace groups across the schooling categories that leads to the foreign born being disproportionately represented among the undereducated categories. In other words, the lower payoff to schooling for the foreign born appears to be driven largely by the consequences of the positive selection in immigration, in particular among immigrants with low levels of schooling.

Chiswick and Miller (2008) also conducted separate analyses for the major foreign birthplace groups in the US, and found that the gap in the payoff to schooling between immigrants and the native born varied with the stage of development of the immigrant's country of origin, being minimal for advanced Western countries, and large for lessdeveloped countries. In each instance of a sizeable gap in the payoff to schooling, however, the general pattern in the decomposition was the same as that which characterises Table $1 .{ }^{7}$

This paper explores whether these findings carry over to the Canadian labour market, whether they hold for females, as well as whether they are sensitive to different assumptions concerning the order in which the adjustments are implemented (i.e., whether the results exhibit path dependence).

\section{DATA}

The data for this analysis are from the 2001 Census of Canada, 3 percent (technically 2.7 percent) Public Use Microdata File (PUMF). This data set contains comprehensive

\footnotetext{
${ }^{6}$ An issue that was not explored was whether the relative importance of under-education to the gap in the payoff to schooling between immigrants and the native born would change if adjustments were first made for differences in over-education and required education.

${ }^{7}$ Chiswick and Miller (2008) focus on males only. The analyses below are extended to females.
} 
information on all the standard labour market and demographic measures. ${ }^{8}$ In determining the sample to use in the statistical analyses, the analyses follow the philosophy behind the sample exclusions used by Baker and Benjamin (1994) and Ferrer and Riddell (2008). Thus the analyses are restricted to full-time, full-year workers aged 25-64 years in order to avoid conflating wage and labour supply issues. ${ }^{9}$ There is also a focus on those employed in the week prior to Census enumeration: the Census question on hours worked for pay relates to this period, and using this information provides an opportunity to conduct analyses using the hourly wage in addition to annual or weekly earnings. It also is consistent with both Baker and Benjamin (1994) and Ferrer and Riddell (2008). The analyses are further restricted to wage and salary earners, to enable a sharper focus on the returns to human capital that are central to the paper: self-employment income will include returns on financial/physical capital as well as a return on human capital. ${ }^{10}$ Self-employment income also appears to be subject to greater reporting errors than wage and salary income. Residents of the Atlantic provinces are excluded from the analysis because of the limited detail provided in the census microdata file on many variables for residents of these provinces.

The study covers all immigrants meeting these restrictions, which gives samples of 24,690 male immigrants and 18,807 female immigrants. Similarly sized comparison groups

\footnotetext{
${ }^{8}$ See Appendix A for the definitions of the dependent and explanatory variables.

${ }^{9}$ Baker and Benjamin (1994) defined full-year using a threshold of 40 weeks worked in 2000, whereas Ferrer and Riddell (2008) use 52 weeks worked. The 40-week cut-off is used here, though a weeks worked variable is included in the analyses. Full-time refers to usually working 30 hours or more per week (Baker and Benjamin, 1994 covered both part-time and full-time workers, though they included a number of hours of work dummy variables in their estimating equation). Ferrer and Riddell (2008) focus on 16-64 year olds, as do Baker and Benjamin (1994). The 25 years of age lower threshold will reduce the potential impact of selectivity issues associated with study commitments among young adults.

${ }^{10}$ Ferrer and Riddell (2008) include only wage and salary income. Baker and Benjamin (1994), however, include all those with positive earnings, defined as the sum of wage and salary and self-employment earnings.
} 
of the native born (22,852 males and 19,291 females) are obtained by using a 30 percent random sample from the Census PUMF. ${ }^{11}$

These sample restrictions do not match exactly those of any previous study. However, like Ferrer and Riddell (2008), who report that variations of their sample restrictions have little effect on the statistical results, we find that similar changes in the cutoffs have little effect on the material findings.

The variables used in this study are defined in Appendix A. There are three variables that are central to the analysis, earnings, years of schooling, and the required or usual level of schooling in each occupation, and some comment on these is in order. Earnings are the sum of wage and salary earnings. ${ }^{12}$ The years of schooling variable is based on Ferrer and Riddell (2008), and is defined as the sum of years of schooling completed in primary and secondary school, in university, and in post-secondary institutions other than universities. We experimented with alternative definitions, formed using years of schooling equivalents for the highest level of schooling completed, and found that this was of little consequence for the analysis. The required or usual level of schooling is derived using a Realized Matches procedure. It is given as the mean level of schooling of all workers, male or female, in each occupation. Previous analyses (e.g., Hartog, 2000; Chiswick and Miller, 2008; Chiswick and Miller, 2009) have demonstrated that the material findings from application of the ORU specification of the earnings function are not sensitive to the measurement of the reference or usual level of schooling in the respondent's occupation.

\footnotetext{
${ }^{11}$ Ferrer and Riddell (2008) use a 0.25 sampling fraction. Baker and Benjamin (1994) use a 1 in 6 random sample for the native born other than for blacks (for whom all records were used).

${ }^{12}$ Self-employment earnings are included for those who worked mainly as wage and salary earners. Self-employment earnings, however, account for only 1 percent of total earnings in the sample under study.
} 


\section{STATISTICAL ANALYSIS}

\section{(a) $\quad$ Aggregate-Level Regression Analyses}

Table 2 lists selected estimates of the conventional (column (i)) and ORU (column (ii)) versions of the earnings equations for males. It also includes the mean and standard deviation of the selected regressors. The estimates on the left-hand side are for the native born, and those on the right-hand side are for the foreign born. Table 3, which has a structure identical to that of Table 2, is for females. The full sets of results are presented in Appendix B, Tables B.1 and B.2.

According to Table 2, column (i), the return to an additional year of schooling for the native born is 7.7 percent. The comparable rate of return for the foreign born is 1.6 percentage points lower, at 6.1 percent. This magnitude of difference in payoffs to schooling between the native born and the immigrants is consistent with the studies by Baker and Benjamin (1994) and Ferrer and Riddell (2008). Among females (Table 4, column (i)), the payoff to schooling is 10.2 percent for the native born, and 6.9 percent for the foreign born. The wider gap is the payoffs to schooling between the native born and foreign born for females (3.3 percentage points) than for males (1.6 percentage points) is consistent with the findings reported by Ferrer and Riddell (2008).

Among males, the return to the usual or reference years of education for the native born is 12.3 percent (see Table 2, column (ii)), which is almost five percentage points higher than the return to actual years of schooling. It is higher because the return captures two factors: the possession of an additional year of schooling within one's occupation, and mobility to an occupation where the additional year of schooling can be used effectively.

The return to the reference years of education for foreign-born males is 14.5 percent. The difference between returns to the actual years of schooling and required schooling is 
greater among the foreign born ( 8.4 percentage points) than the native born (4.6 percentage points). This implies that labour market matching is more important to earnings determination for the foreign born than it is for the native born. This pattern is also a feature of the US labour market (Chiswick and Miller, 2008).

The return to reference years of schooling is higher for females than for males, for both the native born (17.4 percent for females compared to 12.3 percent for males) and foreign born (16.0 percent for females compared to 14.5 percent for males). The increments in earnings associated with correctly matched schooling were greater for females than for males in many of the studies summarised by Hartog (2000).

An additional year of surplus schooling is associated with 5.5 percent higher earnings for native-born males and 3.5 percent higher earnings for foreign-born males. Thus, the returns associated with over-education are only 25 percent (foreign born) to 45 percent (native born) of the returns associated with correctly matched schooling. Among females, the payoff to surplus schooling for the native born, at 7.4 percent, is 43 percent of the payoff to correctly matched schooling (17.4 percent). The payoff to surplus schooling for foreign-born females, at 3.8 percent, is 24 percent of the payoff to correctly matched schooling (16.0 percent). These relativities are broadly the same as for the male labour market. Moreover, the fact that years of surplus schooling attract a relatively low return for the foreign born mirrors findings for the US labour market. This feature of the returns to surplus education is likely to reflect the less-than-perfect international transferability of schooling acquired abroad. It could also, however, reflect unmeasured quality differences in schooling acquired in Canada and in other countries. 
Table 2

Selected Estimates of Conventional and ORU Earnings Equations, Adult Males in Paid Employment, Canada, 2001 Census $^{(a)}$

\begin{tabular}{|c|c|c|c|c|c|c|}
\hline \multirow[b]{2}{*}{ Variable } & \multicolumn{3}{|c|}{ Native Born } & \multicolumn{3}{|c|}{ Foreign Born } \\
\hline & (i) & (ii) & Mean/(SD) & (iv) & (v) & Mean/(SD) \\
\hline $\begin{array}{l}\text { Actual } \\
\text { Education }\end{array}$ & $\begin{array}{c}0.077 \\
(35.12)\end{array}$ & (c) & $\begin{array}{l}14.018 \\
(3.09)\end{array}$ & $\begin{array}{c}0.061 \\
(27.38)\end{array}$ & (c) & $\begin{array}{l}14.404 \\
(3.57)\end{array}$ \\
\hline $\begin{array}{l}\text { Usual } \\
\text { Education }^{(\mathrm{b})}\end{array}$ & (c) & $\begin{array}{c}0.123 \\
(34.07)\end{array}$ & $\begin{array}{l}13.867 \\
(1.63)\end{array}$ & (c) & $\begin{array}{c}0.145 \\
(34.85)\end{array}$ & $\begin{array}{l}13.925 \\
(1.66)\end{array}$ \\
\hline Over-education & (c) & $\begin{array}{c}0.055 \\
(13.66)\end{array}$ & $\begin{array}{l}1.112 \\
(1.55)\end{array}$ & (c) & $\begin{array}{l}0.035 \\
(8.05)\end{array}$ & $\begin{array}{l}1.446 \\
(1.77)\end{array}$ \\
\hline Under-education & (c) & $\begin{array}{l}-0.061 \\
(11.06)\end{array}$ & $\begin{array}{l}0.961 \\
(1.55)\end{array}$ & (c) & $\begin{array}{r}-0.031 \\
(6.05)\end{array}$ & $\begin{array}{l}0.966 \\
(1.83)\end{array}$ \\
\hline $\begin{array}{l}\text { Other Control } \\
\text { Variables Included }\end{array}$ & Yes & Yes & - & Yes & Yes & - \\
\hline$\overline{\mathrm{R}}^{2}$ & 0.102 & 0.111 & - & 0.109 & 0.129 & - \\
\hline Sample Size & 25,852 & 25,852 & 25,852 & 24,690 & 24,690 & 24,690 \\
\hline
\end{tabular}

Notes: (a) Heteroscedasticity consistent " $t$ " statistics in parentheses.

(b) Computed using the Realised Matches procedure as the reference level of schooling.

(c) Variable not entered into specification.

(d) Other control variables are years of potential labour market experience and its square, weeks worked, married, resident of Census Metropolitan Area, fluent in English or French, province of residence, and for the foreign born, duration of residence in Canada and its square and citizenship status.

Dependent variable: Natural logarithm of earnings in 2000.

Source: 2001 Canadian Census PUMS.

Table 3 Selected Estimates of Conventional and ORU Earnings Equations, Adult Females in Paid
Employment, Canada, 2001 Census $^{(\text {a) }}$

\begin{tabular}{|c|c|c|c|c|c|c|}
\hline \multirow[b]{2}{*}{ Variable } & \multicolumn{3}{|c|}{ Native Born } & \multicolumn{3}{|c|}{ Foreign Born } \\
\hline & (i) & (ii) & Mean/(SD) & (iv) & (v) & Mean/(SD) \\
\hline $\begin{array}{l}\text { Actual } \\
\text { Education }\end{array}$ & $\begin{array}{c}0.102 \\
(37.23)\end{array}$ & (c) & $\begin{array}{l}14.326 \\
(2.90)\end{array}$ & $\begin{array}{c}0.069 \\
(25.42)\end{array}$ & (c) & $\begin{array}{l}14.230 \\
(3.45)\end{array}$ \\
\hline $\begin{array}{l}\text { Usual } \\
\text { Education }^{(\mathrm{b})}\end{array}$ & (c) & $\begin{array}{c}0.174 \\
(39.39)\end{array}$ & $\begin{array}{l}14.481 \\
(1.54)\end{array}$ & (c) & $\begin{array}{c}0.160 \\
(32.66)\end{array}$ & $\begin{array}{l}14.136 \\
(1.59)\end{array}$ \\
\hline Over-education & (c) & $\begin{array}{c}0.074 \\
(12.57)\end{array}$ & $\begin{array}{l}0.936 \\
(1.37)\end{array}$ & (c) & $\begin{array}{l}0.038 \\
(6.97)\end{array}$ & $\begin{array}{l}1.224 \\
(1.60)\end{array}$ \\
\hline Under-education & (c) & $\begin{array}{l}-0.068 \\
(9.67)\end{array}$ & $\begin{array}{l}1.091 \\
(1.46)\end{array}$ & (c) & $\begin{array}{r}-0.040 \\
(6.94)\end{array}$ & $\begin{array}{l}1.130 \\
(1.86)\end{array}$ \\
\hline $\begin{array}{l}\text { Other Control } \\
\text { Variables Included }\end{array}$ & Yes & Yes & - & Yes & Yes & - \\
\hline$\overline{\mathrm{R}}^{2}$ & 0.116 & 0.135 & - & 0.102 & 0.126 & - \\
\hline Sample Size & 19,291 & 19,291 & 19,291 & 18,807 & 18,807 & 18,807 \\
\hline
\end{tabular}

Notes: See Table 2.

Source: 2001 Canadian Census PUMS. 
Years of under-education are associated with lower earnings, compared to workers in the same occupation who have the usual level of schooling for that occupation. The earnings penalty for under-education is 6.1 percent for native-born males, and 3.1 percent for foreignborn males. It is 6.8 percent for native-born females, and 4.0 percent for foreign-born females. The smaller (in absolute value) earnings penalty associated with years of undereducation for the foreign born than for the native born is similar to the way earnings are structured in the US labour market. Chiswick and Miller (2008) argue that this is likely to be a reflection of the foreign born at lower levels of schooling possessing greater levels of unobservables that are positively associated with earnings, and that this can be linked to immigrant self-selection.

Thus, the Canadian and US labour markets exhibit similar reward/penalty systems in terms of payoffs to correctly matched and mismatched educational attainment. While the magnitude of the payoffs vary between the two countries, as indeed is also the case for the return to actual years of schooling, there is no conflict in terms of the overall patterns in the empirical findings.

\section{(b) $\quad$ Aggregate-Level Decompositions}

Tables 4 (males) and 5 (females) report the results of the decomposition of the gap in the returns to education between native-born and foreign-born workers.

The payoff to education for native-born males computed from the means of the predicted earnings at each level of schooling is 7.6 percent. For foreign-born males the implied payoff to schooling is 6.0 percent.

If it is assumed that the effects on earnings of the ORU variables are the same for the foreign born as they are for the native born, then the payoff to schooling for the foreign born would increase by 1.4 percentage points, to 7.4 percent, among males, and it would increase 
by 2.7 percentage points, to 9.5 percent, among females. These changes represent 88 percent of the gap in the payoff to schooling for the two birthplace groups in the case of males, and 84 percent of the gap in the case of females. For males in the US labour market, Chiswick and Miller's (2008) calculations show that this adjustment accounts for 62 percent of the much greater gap in the payoffs to schooling for the native born and immigrants.

\section{Table 4}

Implied Payoffs to Schooling, Adjusting for Effects of ORU Variables, Canada, Males

Native-born males

\% Payoff

Foreign-born males

7.6

- no adjustment

a) assuming same earnings effects to reference education, under-education and over-education as native-born males

b) as for (a) but also same levels of reference education, under-education and over-education within each schooling category as native-born males

c) as for (b) but also assuming same distribution across schooling categories for foreign-born males as for nativeborn males

Source: Authors' calculations.

Table 5

Implied Payoffs to Schooling, Adjusting for Effects of ORU Variables, Canada, Females

Native-born females

$\underline{\% \text { Payoff }}$

Foreign-born females

10.0

- no adjustment

a) assuming same earnings effects to reference education, under-education and over-education as native-born females

b) as for (a) but also same levels of reference education, under-education and over-education within each schooling category as native-born females

c) as for (c) but also assuming same distribution across schooling categories for foreign-born females as for native-born females

Source: Authors' calculations. 
The further adjustment for the mean levels of the ORU variables (i.e., equation (5)) results in only a minor upward change of 0.1 percentage point in the payoff to schooling for both foreign-born males and foreign-born females in the Canadian labour market. This mirrors the minor 0.1 percentage point change reported by Chiswick and Miller (2008) for the US labour market, and it follows from the broad similarity in the distributions of the native born and the foreign born across the educational match/mismatch categories at each level of schooling.

Finally, the adjustment for the different distributions of the foreign born and native born across schooling categories results in a further, very small, increase in the payoff to schooling for the foreign-born men (by 0.1 percentage point) and a somewhat larger amount (by 0.4 percentage point) for females. These changes contrast with the 1.9 percentage points effect associated with this adjustment in the US (see Table 1). Unlike the US, Canada does not have a high representation of very low-educated immigrants, and it is this absence that accounts for this difference. ${ }^{13}$

These analyses suggest, therefore, that it is the earnings effects associated with the ORU variables that have the greatest impact on the differences between the payoffs to actual years of schooling received by immigrants and the native born. Given this, the calculations were repeated changing the three earnings effects (to reference levels of education, years of under-education and years of over-education) one at a time. These adjustments showed slightly different patterns for men and women, owing to the return to reference years of schooling being higher for foreign-born men than for native-born men, and lower for foreignborn women than for native-born women. Thus, adjustment for the payoffs to reference years of schooling is actually associated with a widening of the gap in the payoffs to actual years of

\footnotetext{
${ }^{13}$ Antecol, Cobb-Clark and Trejo (2003) have drawn attention to the importance in the US of Latin American immigrants, especially those from Mexico, with low schooling when making comparisons between the US and Canada.
} 
schooling by 0.5 percentage point for males, and a narrowing of this gap by 0.3 percentage point for females (see Appendix Tables B.3 and B.4). Adjustment for the earnings effects of under-education was associated with a narrowing of the gap in the payoffs to schooling by 1.2 percentage points for males and by 1.3 percentage points for females. Adjustment for the earnings effects of over-education was associated with a narrowing of the gap in the returns to schooling by 0.7 percentage points for males and by 1.1 percentage points for females. Hence, both the earnings effects of over-education and under-education contribute to the differential in the payoffs to schooling for immigrants and the native born in Canada, though under-education is slightly more important in this regard. This contrasts with the situation in the US, were the under-education phenomenon was much more important (Chiswick and Miller, 2008).

The potential impact of path dependence was examined by repeating the calculations in Tables 4 and 5 by first standardising for the mean values of the ORU variables (i.e., the adjustment outlined in equation 5) and then standardising for the coefficients of the ORU model (i.e., the adjustment outlined in equation 4). This sensitivity test revealed that path dependence is not an issue.

A second type of path dependence involves the order in which the ORU coefficients are used to examine their relative importance. In the examination discussed above, the order of replacement was " $\mathrm{R}$ ", "U" and then "O". Reversing this order has little material impact on the findings. Detailed calculations are presented in Appendix B, Tables B.5 and B.6. ${ }^{14}$

14 When the gender difference in the payoffs to schooling is examined using this decomposition, the results are as follows. Among the native born, of the 2.4 percentage point gap in the payoffs, fully 96 percent is linked to differences in estimated coefficients, and of this amount, 61 percent is due to differences in the payoffs to reference levels of schooling, 13 percent to differences in the payoffs to under-education and 26 percent due to differences in the payoffs to over-education. In the case of the foreign born, all of the 0.8 percentage point gap in the payoffs to schooling is due to differences in estimated coefficients, with the reference and under-education variables making approximately equal contributions in this regard. 
Chiswick and Miller (2008) associated the smaller payoff to over-education for immigrants than for the native born with the less-than-perfect international transferability of schooling acquired abroad. They associate the smaller (in absolute value) earnings effect of under-education for immigrants than for the native born to favourable selection in migration that results in immigrants with low levels of schooling obtaining jobs for which their paper qualifications suggest they are under-qualified. This self-selection in migration will be more intense among the less-well educated (where under-education is a characteristic) where there are fixed costs of migration (Chiswick, 1999). Thus, within this framework, the decomposition results reported in Tables 4 and 5 suggest that both the less-than-perfect international transferability of human capital and self-selection in migration contribute to the relatively low payoff to schooling for the foreign born in the Canadian labour market. This is the case for both males and females.

\section{(c) Analyses by Age at Migration}

The variables on date of birth and year of migration in the 2001 Census of Canada, together with an estimated month of migration, permit the computation of the age at migration. In the PUMS file, age at migration is provided in broad bands: 0-4 years, 5-12 years, 13-19 years and then in 5-year bands to age 55-59. The upper category is 60 years and over.

Immigrants who arrived as children, and hence completed all or some of their schooling in Canada, and those who arrived as adults, and hence would not usually have undertaken any of their schooling in Canada, can be categorised in various ways using this information. For example, child immigrants might be categorised as those who arrived before they turned 12. Adult immigrants might be those who arrived at age 20 or more. Ferrer and Riddell (2008) used arrival in Canada before age 20 to define a "youth" sample, and arrival at 
or after age 20 and after age 34 as alternative definitions of adult samples. They note that these separations "imperfectly control for Canadian acquired education" (Ferrer and Riddell, 2008, p.196).

The current analysis also employs alternative definitions of "adult" and "youth" immigrants. ${ }^{15}$ Adult is defined using age 20 or more, 25 or more, 30 or more and 35 or more as the lower threshold age at migration. Youth/child at migration is defined using age 19 or younger, and age 12 or younger as the upper threshold. Selected results from the ORU and conventional models of earnings determination using these alternatives are presented in Table 6 for males and in Table 7 for females. These tables also include, for comparison purposes, the earlier results for the native born and total foreign born in the final two rows.

Table 6

Selected Estimates of Conventional and ORU Models of Earnings by Age at Arrival, Canada, Males

\begin{tabular}{|c|c|c|c|c|c|c|}
\hline $\begin{array}{l}\text { Age at } \\
\text { Arrival }\end{array}$ & $\begin{array}{c}\text { Years of } \\
\text { Actual } \\
\text { Education }\end{array}$ & $\begin{array}{c}\text { Years of } \\
\text { Over- } \\
\text { education }\end{array}$ & $\begin{array}{c}\text { Years of } \\
\text { Usual } \\
\text { Education } \\
\end{array}$ & $\begin{array}{c}\text { Years of } \\
\text { Under- } \\
\text { education }\end{array}$ & $\mathrm{R}^{2}$ & $\begin{array}{l}\text { Sample } \\
\text { Size }\end{array}$ \\
\hline \multicolumn{7}{|l|}{ Child Immigrants } \\
\hline$\leq$ Age 12 & $\begin{array}{c}0.068 \\
(11.62)\end{array}$ & $\begin{array}{l}0.038 \\
(3.79)\end{array}$ & $\begin{array}{c}0.129 \\
(15.52)\end{array}$ & $\begin{array}{l}-0.044 \\
(4.08)\end{array}$ & 0.109 & 5,182 \\
\hline$\leq$ Age 19 & $\begin{array}{c}0.065 \\
(15.69)\end{array}$ & $\begin{array}{l}0.035 \\
(4.63)\end{array}$ & $\begin{array}{c}0.137 \\
(20.88)\end{array}$ & $\begin{array}{l}-0.042 \\
(5.15)\end{array}$ & 0.124 & 8,533 \\
\hline \multicolumn{7}{|l|}{ Adult Immigrants } \\
\hline$\geq$ Age 20 & $\begin{array}{c}0.057 \\
(19.23)\end{array}$ & $\begin{array}{l}0.032 \\
(5.84)\end{array}$ & $\begin{array}{c}0.147 \\
(26.65)\end{array}$ & $\begin{array}{l}-0.025 \\
(3.73)\end{array}$ & 0.132 & 15,862 \\
\hline$\geq$ Age 25 & $\begin{array}{c}0.055 \\
(15.06)\end{array}$ & $\begin{array}{l}0.032 \\
(4.84)\end{array}$ & $\begin{array}{c}0.152 \\
(22.70)\end{array}$ & $\begin{array}{l}-0.018 \\
(2.27)\end{array}$ & 0.133 & 11,784 \\
\hline$\geq$ Age 30 & $\begin{array}{l}0.048 \\
(9.64)\end{array}$ & $\begin{array}{l}0.028 \\
(3.34)\end{array}$ & $\begin{array}{c}0.159 \\
(17.35)\end{array}$ & $\begin{array}{l}-0.004 \\
(0.41)\end{array}$ & 0.125 & 7,282 \\
\hline$\geq$ Age 35 & $\begin{array}{l}0.042 \\
(5.47)\end{array}$ & $\begin{array}{l}0.019 \\
(1.62)\end{array}$ & $\begin{array}{c}0.158 \\
(11.57)\end{array}$ & $\begin{array}{l}-0.009 \\
(0.61)\end{array}$ & 0.117 & 4,006 \\
\hline $\begin{array}{l}\text { Total Foreign } \\
\text { Born }\end{array}$ & $\begin{array}{c}0.061 \\
(27.38)\end{array}$ & $\begin{array}{l}0.035 \\
(8.05)\end{array}$ & $\begin{array}{c}0.145 \\
(34.85)\end{array}$ & $\begin{array}{l}-0.031 \\
(6.05)\end{array}$ & 0.129 & 24,690 \\
\hline Native Born & $\begin{array}{c}0.077 \\
(35.12)\end{array}$ & $\begin{array}{c}0.055 \\
(13.66)\end{array}$ & $\begin{array}{c}0.123 \\
(34.07)\end{array}$ & $\begin{array}{l}-0.061 \\
(11.06)\end{array}$ & 0.111 & 25,852 \\
\hline
\end{tabular}

Note: $\mathrm{R}^{2}$ is for the ORU model. See Notes to Table 2.

Source: 2001 Canadian Census PUMS.

${ }^{15}$ The information in the PUMS on age and year of arrival could be used to construct an alternative age at arrival variable that has more categories. We use the Census provided derived variable to assist replication by other researchers of the results presented in this section. 
The first column of results for males and females in Tables 6 and 7, respectively, is for years of actual education. It is seen that the payoff to actual years of education falls with an older age at migration. That is, as one moves down the column, from the foreign born who are highly likely to have undertaken all or most of their schooling in Canada, to samples that also include some foreign born who may have undertaken all or most of their schooling abroad, to samples that will largely comprise the foreign born who completed all their schooling abroad, the coefficient on actual years of schooling falls. Thus, when the sample is restricted to immigrants who arrived in Canada before they turned 13 years of age, the payoff to years of schooling is 6.8 percent among males, and 8.4 percent among females. These payoffs compare with the payoffs of 7.7 percent (males) and 10.2 percent (females) for the native born, and 6.1 percent (males) and 6.9 percent (females) for the total foreign-born sample. When the sample is restricted to immigrants who arrived in Canada after age 34, however, the payoff to actual years of schooling is the much lower, 4.2 percent for males and 4.5 percent for females. Clearly age at migration matters to the payoff to schooling, and the impact is in the expected direction (see Friedberg, 2000), with child immigrants having a payoff to schooling that is much more like that of the native born than is the case for adult immigrants. $^{16}$

The next three columns in Tables 6 and 7 are from the ORU specification of the earnings equation. The general conclusion that can be drawn from these results mirrors that established for the years of actual education variable: the payoffs to the ORU variables for child immigrants are closer to those for the native born than are the respective estimates for adult immigrants. For example, among males, when the sample is restricted to immigrants who arrived in Canada before they turned 13 years of age, the payoff to usual years of schooling is 12.9 percent, which is similar to the 12.3 percent payoff for the native born.

\footnotetext{
${ }^{16}$ Similar findings are reported by Schaafsma and Sweetman (2001, p.1093) when they focus on the returns of schooling by age-at-arrival category.
} 
Among females, the payoff to usual years of schooling for this group of child immigrants is 17.4 percent, which is the same as for the native born.

\section{Table 7}

Selected Estimates of Conventional and ORU Models of Earnings by Age at Arrival, Canada, Females

\begin{tabular}{|lcccccc|}
\hline $\begin{array}{l}\text { Age at } \\
\text { Arrival }\end{array}$ & $\begin{array}{c}\text { Years of } \\
\text { Actual } \\
\text { Education }\end{array}$ & $\begin{array}{c}\text { Years of } \\
\text { Over- } \\
\text { education }\end{array}$ & $\begin{array}{c}\text { Years of } \\
\text { Usual } \\
\text { Education }\end{array}$ & $\begin{array}{c}\text { Years of } \\
\text { Under- } \\
\text { education }\end{array}$ & $\mathrm{R}^{2}$ & $\begin{array}{c}\text { Sample } \\
\text { Size }\end{array}$ \\
\hline Child Immigrants & & & & & & \\
SAge 12 & 0.084 & 0.040 & 0.174 & -0.063 & 0.122 & 3,975 \\
& $(12.06)$ & $(3.05)$ & $(16.54)$ & $(3.97)$ & & \\
SAge 19 & 0.080 & 0.055 & 0.167 & -0.050 & 0.120 & 6,709 \\
& $(16.51)$ & $(6.02)$ & $(20.23)$ & $(4.90)$ & & \\
Adult Immigrants & & & & & & \\
$\geq$ Age 20 & 0.064 & 0.032 & 0.156 & -0.036 & 0.123 & 11,896 \\
& $(18.16)$ & $(4.61)$ & $(24.66)$ & $(5.11)$ & & \\
$\geq$ Age 25 & 0.062 & 0.031 & 0.152 & -0.038 & 0.117 & 8,245 \\
& $(13.40)$ & $(3.75)$ & $(18.80)$ & $(4.11)$ & & \\
$\geq$ Age 30 & 0.056 & 0.033 & 0.143 & -0.029 & 0.113 & 4,923 \\
& $(8.94)$ & $(2.95)$ & $(13.02)$ & $(2.34)$ & & \\
$\geq$ Age 35 & 0.045 & 0.022 & 0.131 & -0.027 & 0.112 & 2,641 \\
& $(4.88)$ & $(1.48)$ & $(7.97)$ & $(1.54)$ & & \\
\hdashline Total Foreign & 0.069 & 0.038 & 0.160 & -0.040 & 0.126 & 18,807 \\
Born & $(25.42)$ & $(6.97)$ & $(32.66)$ & $(6.94)$ & & \\
Native Born & 0.102 & 0.074 & 0.174 & -0.068 & 0.135 & 19,291 \\
& $(37.23)$ & $(12.57)$ & $(39.39)$ & $(9.67)$ & & \\
\hline
\end{tabular}

Note: $\mathrm{R}^{2}$ is for the ORU model. See Notes to Table 2.

Source: 2001 Canadian Census PUMS.

There are two features of the estimates of the effects on earnings of over-education and under-education that should be noted.

First, among both males and females, the payoff to years of over-education is negligible among the group of adult immigrants with the highest threshold age at migration. Thus, the group assumed to have the greatest component of their schooling acquired abroad has the smallest payoff to surplus schooling. This adds to the suggestion that the smaller payoff to years of over-education for the foreign born than for the native born is due to the less-than-perfect international transferability of schooling acquired abroad. 
Second, the negative earnings effect of years of under-education is more pronounced among child immigrants than it is among adult immigrants. Indeed, among immigrants who were at least 35 years of age when they arrived in Canada, the effect of years of undereducation on earnings is negligible. This means that these immigrants have about the same earnings as their better-educated counterparts who work in the same occupation. As such, it is presumed that they have relatively higher endowments of unobservables that are favourable to earnings determination in Canada. According to the Chiswick and Miller (2008) model, this implies that adult immigrants to Canada are more intensely favourably selected for immigration than child immigrants — who presumably were tied movers.

Attention is now turned to the decomposition of the difference between the payoffs to schooling for adult and child immigrants and the native born. Results of the decompositions are displayed in Table 8 (males) and Table 9 (females).

Table 8

\section{Decomposition of Immigrant/Native-Born Difference in Payoff to Education by Immigrant's Age at Arrival, Canada, Males}

\begin{tabular}{|c|c|c|c|c|c|c|c|}
\hline $\begin{array}{l}\text { Age at } \\
\text { Arrival }\end{array}$ & $\begin{array}{c}\text { Payoff: } \\
\text { Native } \\
\text { Born } \\
\text { (i) }\end{array}$ & $\begin{array}{c}\text { Payoff: } \\
\text { Foreign } \\
\text { Born } \\
\text { (ii) }\end{array}$ & $\begin{array}{c}\text { Payoff: } \\
\text { Foreign } \\
\text { Born } \\
\text { Adjusting } \\
\text { for } \\
\text { Estimated } \\
\text { R Effect } \\
\text { (iii) }\end{array}$ & $\begin{array}{c}\text { Payoff: } \\
\text { Foreign } \\
\text { Born } \\
\text { Adjusting } \\
\text { for } \\
\text { Estimated } \\
\text { RU } \\
\text { Effects } \\
\text { (iv) }\end{array}$ & $\begin{array}{c}\text { Payoff: } \\
\text { Foreign } \\
\text { Born } \\
\text { Adjusting } \\
\text { for } \\
\text { Estimated } \\
\text { ORU } \\
\text { Effects } \\
\text { (v) }\end{array}$ & $\begin{array}{c}\text { Payoff: } \\
\text { Foreign } \\
\text { Born } \\
\text { Adjusting } \\
\text { for Means } \\
\text { of ORU } \\
\text { Variables } \\
\text { (vi) }\end{array}$ & $\begin{array}{c}\text { Payoff: } \\
\text { Foreign } \\
\text { Born } \\
\text { Adjusting } \\
\text { for } \\
\text { Weights } \\
\text { (vii) } \\
\end{array}$ \\
\hline \multicolumn{8}{|c|}{ Child Immigrants } \\
\hline$\leq$ Age 12 & 7.6 & 6.6 & 6.4 & 7.0 & 7.6 & 7.6 & 7.6 \\
\hline$\leq$ Age 19 & 7.6 & 6.5 & 6.1 & 6.9 & 7.6 & 7.5 & 7.6 \\
\hline \multicolumn{8}{|c|}{ Adult Immigrants } \\
\hline$\geq$ Age 20 & 7.6 & 5.6 & 5.0 & 6.5 & 7.4 & 7.4 & 7.6 \\
\hline$\geq$ Age 25 & 7.6 & 5.5 & 4.8 & 6.6 & 7.4 & 7.5 & 7.6 \\
\hline$\geq$ Age 30 & 7.6 & 4.9 & 4.1 & 6.4 & 7.3 & 7.5 & 7.6 \\
\hline$\geq$ Age 35 & 7.6 & 4.5 & 3.7 & 5.9 & 7.2 & 7.5 & 7.6 \\
\hline $\begin{array}{l}\text { Total } \\
\text { Foreign } \\
\text { Born }\end{array}$ & 7.6 & 6.0 & 5.5 & 6.7 & 7.4 & 7.5 & 7.6 \\
\hline
\end{tabular}

Source: Authors' calculations. 
Table 9

\section{Decomposition of Immigrant/Native-Born Difference in Payoff to Education by Immigrant's Age at Arrival, Canada, Females}

\begin{tabular}{|c|c|c|c|c|c|c|c|}
\hline $\begin{array}{l}\text { Age at } \\
\text { Arrival }\end{array}$ & $\begin{array}{c}\text { Payoff: } \\
\text { Native } \\
\text { Born } \\
\text { (i) }\end{array}$ & $\begin{array}{c}\text { Payoff: } \\
\text { Foreign } \\
\text { Born } \\
\text { (ii) }\end{array}$ & $\begin{array}{l}\text { Payoff: } \\
\text { Foreign } \\
\text { Born } \\
\text { Adjusting } \\
\text { for } \\
\text { Estimated } \\
\text { R Effect } \\
\text { (iii) }\end{array}$ & $\begin{array}{c}\text { Payoff: } \\
\text { Foreign } \\
\text { Born } \\
\text { Adjusting } \\
\text { for } \\
\text { Estimated } \\
\text { RU } \\
\text { Effects } \\
\text { (iv) }\end{array}$ & $\begin{array}{c}\text { Payoff: } \\
\text { Foreign } \\
\text { Born } \\
\text { Adjusting } \\
\text { for } \\
\text { Estimated } \\
\text { ORU } \\
\text { Effects } \\
\text { (v) }\end{array}$ & $\begin{array}{c}\text { Payoff: } \\
\text { Foreign } \\
\text { Born } \\
\text { Adjusting } \\
\text { for Means } \\
\text { of ORU } \\
\text { Variables } \\
\text { (vi) }\end{array}$ & $\begin{array}{c}\text { Payoff: } \\
\text { Foreign } \\
\text { Born } \\
\text { Adjusting } \\
\text { for } \\
\text { Weights } \\
\text { (vii) }\end{array}$ \\
\hline \multicolumn{8}{|c|}{ Child Immigrants } \\
\hline$\leq$ Age 12 & 10.0 & 8.2 & 8.2 & 8.4 & 9.6 & 9.9 & 10.0 \\
\hline$\leq$ Age 19 & 10.0 & 8.1 & 8.2 & 9.0 & 9.6 & 9.7 & 10.0 \\
\hline \multicolumn{8}{|c|}{ Adult Immigrants } \\
\hline$\geq$ Age 20 & 10.0 & 6.3 & 6.7 & 8.1 & 9.5 & 9.5 & 10.0 \\
\hline$\geq$ Age 25 & 10.0 & 6.2 & 6.7 & 8.0 & 9.4 & 9.5 & 10.0 \\
\hline$\geq$ Age 30 & 10.0 & 5.6 & 6.2 & 8.0 & 9.3 & 9.4 & 10.0 \\
\hline$\geq$ Age 35 & 10.0 & 4.6 & 5.4 & 7.4 & 9.1 & 9.4 & 10.0 \\
\hline Total & & & & & & & \\
\hline $\begin{array}{l}\text { Foreign } \\
\text { Born }\end{array}$ & 10.0 & 6.8 & 7.1 & 8.4 & 9.5 & 9.6 & 10.0 \\
\hline
\end{tabular}

Source: Authors' calculations.

For each age-at-arrival group, it is quite clear that essentially all of the difference in the payoffs to schooling for that group and the native born is due to the different estimated earnings effects associated with the ORU variables (column (v)). The effects of the adjustment for the means of the ORU variables (column (vi)) are inconsequential in each case, including the decomposition undertaken for adult immigrants. There is, therefore, no evidence that child immigrants have a better "match" in the labour market, at least from the perspective of the impact on earnings.

When the analyses are repeated replacing the estimated coefficients on the ORU variables for the foreign born age-at-arrival groups one at a time, three patterns emerge.

First, adjustment for the earnings effects associated with the reference levels of schooling ("R", see column (iii)) results is a modest decline in the implied payoff to schooling for all groups of foreign-born males and a modest increase in the implied payoff to 
schooling for all groups of foreign-born females. These changes are in line with the aggregate-level results.

Second, the effects of the additional adjustment for the earnings effects of undereducation ("U”, see column (iv)) are more pronounced among adult immigrants than they are among child immigrants. As argued above, child immigrants will comprise tied movers, among whom the effects of favourable selection should be less intense.

Third, the effect of the further adjustment for overeducation ("O", see column (v)) is also more pronounced among adult immigrants than it is among child immigrants. As adult immigrants will have acquired more of their schooling abroad than child immigrants, and hence the effects of limitations on the international transferability of human capital should be more intense for adult than for child immigrants, this pattern of effects is intuitively reasonable.

\section{(d) Analyses by Country of Origin}

The major immigrant groups that can be distinguished using the 2001 Census of Canada PUMS are: (a) US; (b) UK; (c) Other Europe; (d) Asia; and (e) Other countries. ${ }^{17}$ The conventional and ORU models of earnings determination were estimated for each of these groups, and the decomposition undertaken of the difference between the return to schooling for each birthplace group and the native born. Selected regression estimates are presented in Table 10 (males) and Table 11 (females).

The results for each of the major birthplace groups largely mirror the findings for the total foreign-born sample. Thus, the payoff to actual years of schooling for the foreign born

\footnotetext{
${ }^{17}$ The Census birthplace variable has categories for the following foreign birthplaces: (i) US; (ii) UK; (iii) Germany; (iv) Netherlands; (v) Other European Countries; (vi) Asia; and (vii) Other countries and regions.
} 
in each country group is less than that for the native born. For each country group other than Asia, the payoff to actual schooling for females exceeds the payoff for males.

Table 10

\section{Selected Estimates of Conventional and ORU Models of Earnings by}

Country of Origin, Canada, Males

\begin{tabular}{|lcccccc|}
\hline & $\begin{array}{c}\text { Years of } \\
\text { Actual } \\
\text { Bducation }\end{array}$ & $\begin{array}{c}\text { Years of } \\
\text { Over- } \\
\text { education }\end{array}$ & $\begin{array}{c}\text { Years of } \\
\text { Usual } \\
\text { Education }\end{array}$ & $\begin{array}{c}\text { Years of } \\
\text { Under- } \\
\text { education }\end{array}$ & $\mathrm{R}^{2}$ & $\begin{array}{c}\text { Sample } \\
\text { Size }\end{array}$ \\
\hline US & 0.060 & 0.030 & 0.129 & -0.008 & 0.079 & 898 \\
UK & $(4.69)$ & $(1.15)$ & $(6.05)$ & $(0.23)$ & & \\
Other Europe & 0.057 & 0.026 & 0.135 & -0.038 & 0.123 & 2,963 \\
& $(10.05)$ & $(2.66)$ & $(14.04)$ & $(2.72)$ & & \\
Asia & 0.050 & 0.024 & 0.125 & -0.033 & 0.083 & 7,127 \\
& $(12.31)$ & $(2.93)$ & $(15.52)$ & $(4.24)$ & & \\
Other Countries & 0.060 & 0.044 & 0.142 & -0.025 & 0.138 & 8,879 \\
& $(15.97)$ & $(6.09)$ & $(18.85)$ & $(3.28)$ & & \\
Total Foreign & 0.067 & 0.035 & 0.165 & -0.036 & 0.126 & 4,823 \\
Born & $(13.25)$ & $(3.74)$ & $(17.06)$ & $(3.25)$ & & \\
Native Born & 0.061 & 0.035 & 0.145 & -0.031 & 0.129 & 24,690 \\
& $(27.38)$ & $(8.05)$ & $(34.85)$ & $(6.05)$ & & \\
& 0.077 & 0.055 & 0.123 & -0.061 & 0.111 & 25,852 \\
\hline
\end{tabular}

Note: $\mathrm{R}^{2}$ is for the ORU model. See Notes to Table 2.

Source: 2001 Canadian Census PUMS.

Table 11

Selected Estimates of Conventional and ORU Models of Earnings by Country of Origin, Canada, Females

\begin{tabular}{|c|c|c|c|c|c|c|}
\hline Birthplace & $\begin{array}{c}\text { Years of } \\
\text { Actual } \\
\text { Education }\end{array}$ & $\begin{array}{l}\text { Years of } \\
\text { Over- } \\
\text { education }\end{array}$ & $\begin{array}{c}\text { Years of } \\
\text { Usual } \\
\text { Education }\end{array}$ & $\begin{array}{l}\text { Years of } \\
\text { Under- } \\
\text { education }\end{array}$ & $\mathrm{R}^{2}$ & $\begin{array}{c}\text { Sample } \\
\text { Size }\end{array}$ \\
\hline US & $\begin{array}{l}0.088 \\
(7.25)\end{array}$ & $\begin{array}{l}0.036 \\
(1.46)\end{array}$ & $\begin{array}{l}0.151 \\
(7.62)\end{array}$ & $\begin{array}{l}-0.087 \\
(2.45)\end{array}$ & 0.105 & 886 \\
\hline UK & $\begin{array}{l}0.073 \\
(9.83)\end{array}$ & $\begin{array}{l}0.036 \\
(2.36)\end{array}$ & $\begin{array}{c}0.167 \\
(13.07)\end{array}$ & $\begin{array}{l}-0.046 \\
(2.79)\end{array}$ & 0.124 & 2,147 \\
\hline Other Europe & $\begin{array}{c}0.063 \\
(12.69)\end{array}$ & $\begin{array}{l}0.038 \\
(3.47)\end{array}$ & $\begin{array}{c}0.156 \\
(16.23)\end{array}$ & $\begin{array}{l}-0.033 \\
(3.68)\end{array}$ & 0.110 & 5,034 \\
\hline Asia & $\begin{array}{c}0.056 \\
(14.19)\end{array}$ & $\begin{array}{l}0.033 \\
(4.16)\end{array}$ & $\begin{array}{c}0.145 \\
(18.34)\end{array}$ & $\begin{array}{l}-0.030 \\
(3.83)\end{array}$ & 0.135 & 6,804 \\
\hline Other Countries & $\begin{array}{c}0.083 \\
(13.13)\end{array}$ & $\begin{array}{l}0.044 \\
(3.36)\end{array}$ & $\begin{array}{c}0.172 \\
(14.72)\end{array}$ & $\begin{array}{l}-0.061 \\
(4.84)\end{array}$ & 0.116 & 3,936 \\
\hline $\begin{array}{l}\text { Total Foreign } \\
\text { Born }\end{array}$ & $\begin{array}{c}0.069 \\
(25.42)\end{array}$ & $\begin{array}{l}0.038 \\
(6.97)\end{array}$ & $\begin{array}{c}0.160 \\
(32.66)\end{array}$ & $\begin{array}{l}-0.040 \\
(6.94)\end{array}$ & 0.126 & 18,807 \\
\hline Native Born & $\begin{array}{c}0.102 \\
(37.23)\end{array}$ & $\begin{array}{c}0.074 \\
(12.57)\end{array}$ & $\begin{array}{c}0.174 \\
(39.39)\end{array}$ & $\begin{array}{l}-0.068 \\
(9.67)\end{array}$ & 0.135 & 19,291 \\
\hline
\end{tabular}

Note: $\mathrm{R}^{2}$ is for the ORU model. See Notes to Table 2.

Source: 2001 Canadian Census PUMS. 
The results of the decompositions of the difference between the payoff to schooling for each of these major birthplace groups and the native born are presented in Table 12 for males and Table 13 for females.

\section{Table 12}

\section{Decomposition of Immigrant/Native-Born Difference in Payoff to Education by Immigrant's Country of Origin, Canada, Males}

\begin{tabular}{|lccccc|}
\hline Birthplace & $\begin{array}{c}\text { Payoff: } \\
\text { Native Born }\end{array}$ & $\begin{array}{c}\text { Poreign } \\
\text { Born }\end{array}$ & $\begin{array}{c}\text { Payoff: Foreign } \\
\text { Born Adjusting } \\
\text { for Estimated } \\
\text { ORU Effects }\end{array}$ & $\begin{array}{c}\text { Payoff: Foreign } \\
\text { Born Adjusting } \\
\text { for Means of } \\
\text { ORU Variables }\end{array}$ & $\begin{array}{c}\text { Payoff: } \\
\text { Foreign Born } \\
\text { Adjusting for } \\
\text { Weights }\end{array}$ \\
\hline US & 7.6 & 6.1 & 8.2 & 7.8 & 7.6 \\
UK & 7.6 & 5.7 & 7.4 & 7.8 & 7.6 \\
Other Europe & 7.6 & 5.1 & 7.3 & 7.4 & 7.6 \\
Asia & 7.6 & 6.1 & 7.4 & 7.5 & 7.6 \\
Other Countries & 7.6 & 6.8 & 7.4 & 7.5 & 7.6 \\
\hline Total Foreign & 7.6 & 6.0 & 7.4 & 7.5 & 7.6 \\
Born & & & & & \\
\hline
\end{tabular}

Source: Authors' calculations.

Table 13

\section{Decomposition of Immigrant/Native-Born Difference in Payoff to Education by Immigrant's Country of Origin, Canada, Females}

\begin{tabular}{|lccccc|}
\hline Birthplace & $\begin{array}{c}\text { Payoff: } \\
\text { Native Born }\end{array}$ & $\begin{array}{c}\text { Poreff: } \\
\text { Born }\end{array}$ & $\begin{array}{c}\text { Payoff: Foreign } \\
\text { Born Adjusting } \\
\text { for Estimated } \\
\text { ORU Effects }\end{array}$ & $\begin{array}{c}\text { Payoff: Foreign } \\
\text { Born Adjusting } \\
\text { for Means of } \\
\text { ORU Variables }\end{array}$ & $\begin{array}{c}\text { Payoff: } \\
\text { Foreign Born } \\
\text { Adjusting for } \\
\text { Weights }\end{array}$ \\
\hline US & 10.0 & 8.7 & 10.0 & 10.0 & 10.0 \\
UK & 10.0 & 7.3 & 9.7 & 10.0 & 10.0 \\
Other Europe & 10.0 & 6.2 & 9.4 & 9.4 & 10.0 \\
Asia & 10.0 & 5.7 & 9.4 & 9.5 & 10.0 \\
Other Countries & 10.0 & 8.3 & 9.6 & 9.7 & 10.0 \\
Total Foreign & 10.0 & 6.8 & 9.5 & 9.6 & 10.0 \\
Born & & & & & \\
\hline
\end{tabular}

Source: Authors' calculations.

Among males, for each birthplace group, the effects on earnings of years of overeducation, years of usual schooling and years of under-education have the same relativities to the respective estimates for the native born as were established in the aggregate-level 
analysis. With one exception, the same situation is observed in the analyses for females. The exception is the impact of years of under-education among female immigrants from the US. For this group, the estimated effect of years of under-education is -0.087 , which compares with values of -0.040 for the total foreign born, and -0.068 for the native born. This means that this group of under-educated, and presumably low-educated, female immigrants do not do as well as otherwise comparable native-born workers with whom they have an occupation in common. From the perspective of the selectivity in migration hypothesis, this suggests that low-educated females from neighbouring US are less intensely selected for immigration than the typical immigrant, and, indeed, possess fewer unobserved skills than the typical native-born person. In other words, low-educated female immigrants from the US are characterised by less-positive or negative selection in immigration. This could arise where they have a disproportionately high propensity to be tied movers. ${ }^{18}$

The decompositions disaggregated by birthplace have the same general features as the aggregate-level decompositions. Thus, most of the differences in the payoffs to schooling for immigrants from a particular birthplace and the native born is linked to differences in the payoffs of the ORU variables - indeed, standardising for these effects results in an overadjustment in the case of male immigrants from the US. ${ }^{19}$ This is offset by a downward effect of the adjustment for the means of the ORU variables, implying that male immigrants from the US are less likely to be incorrectly matched to the educational requirements of their jobs at a given level of schooling, presumably because the US and Canada are so similar in

\footnotetext{
${ }^{18}$ Of the married female immigrants to Canada born in the US, the spouse's country of birth was 74 percent in Canada, 13 percent in the United States, 8 percent in Europe, 2 percent in Asia, and 3 percent all other places.

19 Tests were conducted to determine whether US born men living in Canada in 2001 who immigrated at ages 18 to 26 years during the Vietnam War era had earnings significantly different from those of other male immigrants from the US. The tests were inconclusive, perhaps because of the small sample size of those young men who came to the US at this time and remained in Canada.
} 
institutions and incomes. ${ }^{20}$ This overall impression of similarity, in the face of minimal variation in the payoff to schooling across the birthplace groups, suggests that the results of the decomposition analysis are robust.

\section{US-CANADA COMPARIONS}

Finally, it is useful to draw explicit comparisons between the US and Canadian labour markets. These comparisons are restricted to males (owing to the focus in the comparison literature), and limited to the findings from application of the decomposition methodology that is the novel contribution of this study. Table 14 lists relevant data.

The first feature of Table 14 is that schooling is associated with a higher payoff for the native born in the US (10.5 percent) than for the native born in Canada (7.6 percent). In contrast, the payoff to schooling for the foreign born in the US, at 5.3 percent, is less than the payoff for the foreign born in Canada (6.0 percent). However, if the focus in the analyses for the US is restricted to immigrants from the developed countries - to make allowance for the Hispanic effect (see Antecol et al., 2003) — the foreign born have a higher payoff to schooling in the US than in Canada.

For both the US and Canada, adjustment for differences in means of the ORU variables at each level of actual schooling has little effect on the implied payoff to schooling. Hence, the first main difference in the results of the decomposition is associated with the fact that in the US, but not in Canada, adjustment for the different distributions of immigrants and the native born across the education categories matters. Consequently, whereas in Canada virtually all of the difference in the payoff to schooling for immigrants and the native born is linked to differences in the estimated effects of the ORU variables, in the US only 62 percent

\footnotetext{
${ }^{20}$ Study of male immigrants from Canada in the US shows that the only adjustment that matters is a slight 0.6 percentage point effect for the distribution across schooling categories (Chiswick and Miller, 2008).
} 
of the gap in the payoffs to schooling is due to this source. In the case of developed countries in the US, the figure is 76 percent: for less-developed countries it is 62 percent.

\section{Table 14}

\section{Cross-Country Comparison of Decomposition of Immigrant/Native-Born Difference in Payoff to Education, Canada and the United States, Males}

\begin{tabular}{|c|c|c|c|c|c|}
\hline Country & $\begin{array}{c}\text { Payoff: } \\
\text { Native } \\
\text { Born }\end{array}$ & $\begin{array}{c}\text { Payoff: } \\
\text { Foreign } \\
\text { Born }\end{array}$ & $\begin{array}{c}\text { Payoff: Foreign } \\
\text { Born Adjusting } \\
\text { for Estimated } \\
\text { ORU Effects }\end{array}$ & $\begin{array}{l}\text { Payoff: Foreign } \\
\text { Born Adjusting } \\
\text { for Means of } \\
\text { ORU Variables }\end{array}$ & $\begin{array}{c}\text { Payoff: } \\
\text { Foreign Born } \\
\text { Adjusting for } \\
\text { Weights }\end{array}$ \\
\hline Canada & 7.6 & 6.0 & 7.4 & 7.5 & 7.6 \\
\hline Canada-Developed & 7.6 & 5.7 & 7.4 & 7.5 & 7.6 \\
\hline Canada-LDC & 7.6 & 6.3 & 7.4 & 7.5 & 7.6 \\
\hline US & 10.5 & 5.3 & 8.5 & 8.6 & 10.5 \\
\hline US-Developed & 10.5 & 7.1 & 9.7 & 9.9 & 10.5 \\
\hline US-LDC & 10.5 & 4.7 & 8.3 & 8.5 & 10.5 \\
\hline
\end{tabular}

Note: Developed in Canada covers the US, UK, Netherlands, Germany and Other Europe.

Source: Table 4 of this paper and Tables 6 and 8 of Chiswick and Miller (2008).

The second main difference arises when the effects on earnings of the ORU variables are considered one at a time. As noted in the previous section, adjustment for the earnings effects of under-education in Canada is associated with a narrowing of the gap in the payoffs to schooling by 1.2 percentage points for males and adjustment for the earnings effects of over-education is associated with a narrowing of the male gap in the returns to schooling by 0.7 percentage points (a ratio of effects of 1.7, showing that under-education is more important in this regard). This compares with the situation in the US, where the undereducation phenomenon was much more important, accounting for 2.0 percentage points of the total coefficients effect compared to the 0.2 percentage point effect for over-education (a ratio of effects of 10) (Chiswick and Miller, 2008). The implication is that the US labour market is characterised by a more intense favourable selection among the large number of low-skilled immigrants compared to Canada, which has few very low-skilled immigrants. 


\section{CONCLUSION}

This paper has examined the reasons for the lower payoff to schooling for the foreign born in the Canadian labour market among both males and females. It applies the decomposition developed by Chiswick and Miller (2008) to assess the determinants of the relative contributions to this low payoff of over-education among the foreign born (which is linked to less-than-perfect international transferability of human capital) and under-education among this group (which is linked to favourable selection in immigration). The results show that while both over-education and under-education contribute to the lower payoff to schooling for the foreign born, it is the latter labour market phenomenon that is more important. However, under-education in the Canadian labour market is far less important than it is in the US.

The low payoff to immigrants' schooling should not necessarily be seen as a matter of concern. The framework used here suggests that only part of this apparent immigrant "disadvantage" is related to a potential labour market problem. This is the part linked to overeducation, the less-than-perfect international transferability of human capital or the nonrecognition of foreign educational credentials. The part that is associated with undereducation is in fact linked to immigrants doing better than what might be expected, given their level of schooling. As such, rather than being linked to disadvantage, this component of the lower payoff to schooling for immigrants is linked to superior labour market outcomes, particularly among the less-well educated.

The role of over-education needs further investigation. This investigation needs to ascertain whether this is simply the result of the less-than-perfect international transferability of immigrants' human capital that was emphasized in the early writings of Chiswick (1978)(1979), or due to quality differences in schooling undertaken in Canada and schooling 
undertaken abroad. ${ }^{21}$ It might also result from barriers to the full recognition of foreign educational credentials due to occupational licensing, cultural differences, employer discrimination or other factors. Policy interventions, including retraining or retooling programs, as well as efforts to increase information about foreign credentials, and combating discrimination, might be fruitful activities.

\footnotetext{
${ }^{21}$ One approach would be to relate the estimates from the ORU model for various birthplace groups to characteristics of the immigrants' countries of origin, such as the internationally standardized scores from the Programme for International Student Assessment (PISA). The limited detail on birthplace among the foreign born prevents pursuing this with the 2001 Census data, but it would be possible with 2000 US Census data. We are grateful to Charles Beach for this suggestion.
} 


\section{REFERENCES}

Abbott, Michael G. and Beach, Charles M., (1993). "Immigrant Earnings Differentials and Birth-Year Effects for Men in Canada: Post-War-1972", Canadian Journal of Economics, Vol. 26, Nol. 3, pp.505-524.

Antecol, Heather, Cobb-Clark, Deborah A. and Trejo, Stephen J., (2003). "Immigrant Policy and the Skills of Immigrants to Australia, Canada and the United States", Journal of Human Resources, Vol. 28, No. 1, pp.192-218.

Baker, Michael and Benjamin, Dwayne, (1994). "The Performance of Immigrants in the Canadian Labor Market”, Journal of Labor Economics, Vol. 12, No. 3, pp.369-405.

Chiswick, Barry R., (1978). "The Effect of Americanization on the Earnings of Foreign-born Men”, Journal of Political Economy, Vol. 86, No. 5, pp. 897-921.

Chiswick, Barry R., (1979). "The Economic Progress of Immigrants: Some Apparently Universal Patterns", pp. 357-99 in William Fellner (ed) Contemporary Economic Problems 1979, American Enterprise Institute for Public Policy Research, Washington, D.C..

Chiswick, Barry R., (1999). “Are Immigrants Favorably Self-Selected?”, American Economic Review, Vol. 89, No. 2, pp.181-185.

Chiswick, Barry R. and Miller, Paul W., (2008). "Why is the Payoff to Schooling Smaller for Immigrants?”, Labour Economics, Vol. 15, No. 6, pp.1317-1340.

Chiswick, Barry R. and Miller, Paul W., (2009). "Does the Choice of Reference Levels of Education Matter in the ORU Earnings Equation?", Xerox, University of Illinois at Chicago.

Ferrer, Ana and Riddell, W. Craig, (2008). "Education, Credentials, and Immigrant Earnings", Canadian Journal of Economics, Vol. 41, No. 1, pp. 186-216.

Friedberg, Rachel M., (2000). "You Can't Take it with You? Immigrant Assimilation and the Portability of Human Capital”, Journal of Labor Economics, Vol. 18, No. 2, pp.221251.

Hartog, Joop, (2000). "Over-education and Earnings: Where Are We, Where Should We Go?", Economics of Education Review, Vol. 19, No. 2, pp. 131-147.

Schaafsma, Joseph and Sweetman, Arthur, (2001). "Immigrant Earnings: Age at Immigration Matters”, Canadian Journal of Economics, Vol. 34, No. 4, pp.1066-1099. 


\section{APPENDIX A}

\section{DEFINITIONS OF VARIABLES}

The variables used in the statistical analyses are defined below.

Data Source: 2001 Census of Canada, Public Use Microdata Sample, 2.7 percent sample of the foreign born, and 0.3 random sample of the native born.

Definition of Population: Native-born and foreign-born men and women aged twenty-five to sixty-four who are classified as being in full-time, full-year paid employment, excluding the Maritime or Atlantic Provinces and those full-time who are self-employed.

\begin{tabular}{|c|c|}
\hline \multicolumn{2}{|l|}{ Dependent Variables } \\
\hline Income in 2000 & $\begin{array}{l}\text { Natural logarithm of earnings in } 2000 \text {, where earnings are defined } \\
\text { as gross earnings from wages/salaries and self-employment } \\
\text { income. }\end{array}$ \\
\hline \multicolumn{2}{|l|}{ Explanatory Variables } \\
\hline Years of Education & $\begin{array}{l}\text { This variable records the total years of full-time equivalent } \\
\text { education. It has been constructed from the Census data on the } \\
\text { total years of schooling completed in primary and secondary } \\
\text { school, in university, and in post-secondary institutions other than } \\
\text { universities. Experimentation with alternative definitions, formed } \\
\text { using years of schooling equivalents for the highest level of } \\
\text { schooling completed, did not result in any major changes to the } \\
\text { findings. }\end{array}$ \\
\hline $\begin{array}{l}\text { Usual Level of } \\
\text { Education }\end{array}$ & $\begin{array}{l}\text { This variable records the required years of education. It is the } \\
\text { mean level of education in the worker's occupation, based on the } \\
\text { Realised Matches procedure. }\end{array}$ \\
\hline $\begin{array}{l}\text { Years of Under- } \\
\text { education }\end{array}$ & $\begin{array}{l}\text { The under-education variable equals the difference between the } \\
\text { years of education that are usual in the person's occupation and } \\
\text { their actual years of education where this computation is positive. } \\
\text { Otherwise, it is set equal to zero. }\end{array}$ \\
\hline Years of Over-education & $\begin{array}{l}\text { The over-education variable equals the difference between the } \\
\text { person's actual years of education and the years of education that } \\
\text { are usual in their occupation where this computation is positive. } \\
\text { Otherwise, it is set equal to zero. }\end{array}$ \\
\hline Weeks worked in 2000 & $\begin{array}{l}\text { This is a continuous variable for the numbers of weeks the } \\
\text { individual worked in } 2000 \text {. }\end{array}$ \\
\hline Experience & Age - Years of Education -6 \\
\hline Metropolitan area & The location variable records residence in a metropolitan area. \\
\hline Province & $\begin{array}{l}\text { Four dichotomous variables have been constructed to record } \\
\text { different provinces and territories: Quebec, Ontario, Prairie, and } \\
\text { British Columbia (the benchmark). Residents of the Atlantic } \\
\text { provinces are excluded. }\end{array}$ \\
\hline Marital Status & $\begin{array}{l}\text { This is a binary variable that distinguishes individuals who are } \\
\text { married (equal to } 1 \text { ) from all other marital states. }\end{array}$ \\
\hline
\end{tabular}


Official Language Proficiency

Years Since Migration

Citizenship
This is a dichotomous variable used to record whether the individual is fluent in English or French.

This is computed from the year the foreign-born person arrived in Canada.

This is a dichotomous variable set equal to one for foreign born who hold Canadian citizenship. 


\section{APPENDIX B}

Table B.1

Estimates of Conventional and ORU Earnings Equations, Adult Males in Paid Employment, Canada Census, 2001 ${ }^{\text {(a) }}$

\begin{tabular}{|c|c|c|c|c|c|c|}
\hline \multirow[b]{2}{*}{ Variable } & \multicolumn{3}{|c|}{ Native Born } & \multicolumn{3}{|c|}{ Foreign Born } \\
\hline & (i) & (ii) & Mean/(SD) & (iv) & (v) & Mean/(SD) \\
\hline Constant & $\begin{array}{l}3.802 \\
(8.13)\end{array}$ & $\begin{array}{l}3.652 \\
(7.82)\end{array}$ & $\begin{array}{c}1.0 \\
(0.0)\end{array}$ & $\begin{array}{l}1.828 \\
(3.47)\end{array}$ & $\begin{array}{l}1.345 \\
(2.57)\end{array}$ & $\begin{array}{l}1.0 \\
(0.0)\end{array}$ \\
\hline $\begin{array}{l}\text { Actual } \\
\text { Education }\end{array}$ & $\begin{array}{c}0.077 \\
(35.12)\end{array}$ & (c) & $\begin{array}{l}14.018 \\
(3.09)\end{array}$ & $\begin{array}{c}0.061 \\
(27.38)\end{array}$ & (c) & $\begin{array}{l}14.404 \\
(3.57)\end{array}$ \\
\hline $\begin{array}{l}\text { Reference } \\
\text { Education }^{(\mathrm{b})}\end{array}$ & (c) & $\begin{array}{c}0.123 \\
(34.07)\end{array}$ & $\begin{array}{l}13.867 \\
(1.63)\end{array}$ & (c) & $\begin{array}{c}0.145 \\
(34.85)\end{array}$ & $\begin{array}{l}13.925 \\
(1.66)\end{array}$ \\
\hline Over-education & (c) & $\begin{array}{c}0.055 \\
(13.66)\end{array}$ & $\begin{array}{l}1.112 \\
(1.55)\end{array}$ & (c) & $\begin{array}{l}0.035 \\
(8.05)\end{array}$ & $\begin{array}{l}1.446 \\
(1.77)\end{array}$ \\
\hline Under-education & (c) & $\begin{array}{l}-0.061 \\
(11.06)\end{array}$ & $\begin{array}{l}0.961 \\
(1.55)\end{array}$ & (c) & $\begin{array}{l}-0.031 \\
(6.05)\end{array}$ & $\begin{array}{l}0.966 \\
(1.83)\end{array}$ \\
\hline Experience (Exp) & $\begin{array}{c}0.037 \\
(17.46)\end{array}$ & $\begin{array}{c}0.037 \\
(17.22)\end{array}$ & $\begin{array}{l}21.048 \\
(10.36)\end{array}$ & $\begin{array}{l}0.016 \\
(5.88)\end{array}$ & $\begin{array}{l}0.020 \\
(7.33)\end{array}$ & $\begin{array}{l}23.421 \\
(10.90)\end{array}$ \\
\hline $\operatorname{Exp}^{2} / 100$ & $\begin{array}{l}-0.055 \\
(11.48)\end{array}$ & $\begin{array}{l}-0.057 \\
(11.61)\end{array}$ & $\begin{array}{l}550.269 \\
(480.34)\end{array}$ & $\begin{array}{l}-0.029 \\
(5.31)\end{array}$ & $\begin{array}{l}-0.037 \\
(6.74)\end{array}$ & $\begin{array}{l}667.336 \\
(544.97)\end{array}$ \\
\hline $\begin{array}{l}\text { Logs Weeks } \\
\text { Worked }\end{array}$ & $\begin{array}{c}1.288 \\
(10.78)\end{array}$ & $\begin{array}{l}1.172 \\
(9.78)\end{array}$ & $\begin{array}{l}3.926 \\
(0.06)\end{array}$ & $\begin{array}{c}1.700 \\
(12.63)\end{array}$ & $\begin{array}{c}1.522 \\
(11.35)\end{array}$ & $\begin{array}{l}3.922 \\
(0.06)\end{array}$ \\
\hline Married & $\begin{array}{c}0.225 \\
(16.14)\end{array}$ & $\begin{array}{c}0.219 \\
(15.78)\end{array}$ & $\begin{array}{l}0.737 \\
(0.44)\end{array}$ & $\begin{array}{l}0.126 \\
(7.34)\end{array}$ & $\begin{array}{l}0.121 \\
(7.13)\end{array}$ & $\begin{array}{l}0.807 \\
(0.39)\end{array}$ \\
\hline Metropolitan & $\begin{array}{c}0.133 \\
(10.79)\end{array}$ & $\begin{array}{l}0.114 \\
(9.26)\end{array}$ & $\begin{array}{l}0.641 \\
(0.48)\end{array}$ & $\begin{array}{l}-0.024 \\
(1.06)\end{array}$ & $\begin{array}{l}-0.036 \\
(1.59)\end{array}$ & $\begin{array}{l}0.899 \\
(0.30)\end{array}$ \\
\hline $\begin{array}{l}\text { Fluent in Official } \\
\text { Languages }\end{array}$ & (c) & (c) & (c) & $\begin{array}{l}0.252 \\
(4.18)\end{array}$ & $\begin{array}{l}0.255 \\
(4.23)\end{array}$ & $\begin{array}{l}0.978 \\
(0.15)\end{array}$ \\
\hline Quebec & $\begin{array}{l}-0.221 \\
(12.50)\end{array}$ & $\begin{array}{c}-0.221 \\
(12.53)\end{array}$ & $\begin{array}{l}0.301 \\
(0.46)\end{array}$ & $\begin{array}{l}-0.221 \\
(7.94)\end{array}$ & $\begin{array}{l}-0.235 \\
(8.52)\end{array}$ & $\begin{array}{l}0.122 \\
(0.33)\end{array}$ \\
\hline Ontario & $\begin{array}{l}-0.036 \\
(2.17)\end{array}$ & $\begin{array}{l}-0.034 \\
(2.07)\end{array}$ & $\begin{array}{l}0.387 \\
(0.49)\end{array}$ & $\begin{array}{l}0.065 \\
(3.52)\end{array}$ & $\begin{array}{l}0.071 \\
(3.86)\end{array}$ & $\begin{array}{l}0.596 \\
(0.49)\end{array}$ \\
\hline Prairie & $\begin{array}{l}-0.100 \\
(5.36)\end{array}$ & $\begin{array}{l}-0.102 \\
(5.45)\end{array}$ & $\begin{array}{l}0.197 \\
(0.40)\end{array}$ & $\begin{array}{l}-0.038 \\
(1.54)\end{array}$ & $\begin{array}{l}-0.040 \\
(1.63)\end{array}$ & $\begin{array}{l}0.125 \\
(0.33)\end{array}$ \\
\hline $\begin{array}{l}\text { Years since } \\
\text { Migration (YSM) }\end{array}$ & (c) & (c) & (c) & $\begin{array}{c}0.033 \\
(15.95)\end{array}$ & $\begin{array}{c}0.033 \\
(16.24)\end{array}$ & $\begin{array}{c}20.64 \\
(13.16)\end{array}$ \\
\hline $\mathrm{YSM}^{2} / 100$ & (c) & (c) & (c) & $\begin{array}{l}-0.038 \\
(9.85)\end{array}$ & $\begin{array}{l}-0.041 \\
(10.63)\end{array}$ & $\begin{array}{c}599.18 \\
(637.86)\end{array}$ \\
\hline Citizen & (c) & (c) & (c) & $\begin{array}{l}0.145 \\
(7.35)\end{array}$ & $\begin{array}{l}0.136 \\
(6.99)\end{array}$ & $\begin{array}{l}0.797 \\
(0.40)\end{array}$ \\
\hline$\overline{\mathrm{R}}^{2}$ & 0.102 & 0.111 & - & 0.109 & 0.129 & - \\
\hline Sample Size & 25,852 & 25,852 & 25,852 & 24,690 & 24,690 & 24,690 \\
\hline
\end{tabular}

Notes: (a) Heteroscedasticity consistent " $t$ " statistics in parentheses.

(b) Computed using the Realized Matches procedure as the reference level of schooling.

(c) Variable not entered into specification.

Dependent variable: Natural logarithm of earnings in 2000.

Source: 2001 Canadian Census PUMS. 
Table B.2

Estimates of Conventional and ORU Earnings Equations, Adult Females in Paid Employment, Canada Census, 2001 ${ }^{(a)}$

\begin{tabular}{|c|c|c|c|c|c|c|}
\hline \multirow[b]{2}{*}{ Variable } & \multicolumn{3}{|c|}{ Native Born } & \multicolumn{3}{|c|}{ Foreign Born } \\
\hline & (i) & (ii) & Mean/(SD) & (iv) & (v) & Mean/(SD) \\
\hline Constant & $\begin{array}{l}2.193 \\
(4.25)\end{array}$ & $\begin{array}{l}1.780 \\
(3.48)\end{array}$ & $\begin{array}{c}1.0 \\
(0.0)\end{array}$ & $\begin{array}{l}1.831 \\
(3.36)\end{array}$ & $\begin{array}{l}1.202 \\
(2.23)\end{array}$ & $\begin{array}{c}1.0 \\
(0.0)\end{array}$ \\
\hline $\begin{array}{l}\text { Actual } \\
\text { Education }\end{array}$ & $\begin{array}{c}0.102 \\
(37.23)\end{array}$ & (c) & $\begin{array}{l}14.326 \\
(2.90)\end{array}$ & $\begin{array}{c}0.069 \\
(25.42)\end{array}$ & (c) & $\begin{array}{l}14.230 \\
(3.45)\end{array}$ \\
\hline $\begin{array}{l}\text { Reference } \\
\text { Education }^{(\mathrm{b})}\end{array}$ & (c) & $\begin{array}{c}0.174 \\
(39.39)\end{array}$ & $\begin{array}{l}14.481 \\
(1.54)\end{array}$ & (c) & $\begin{array}{c}0.160 \\
(32.66)\end{array}$ & $\begin{array}{l}14.136 \\
(1.59)\end{array}$ \\
\hline Over-education & (c) & $\begin{array}{c}0.074 \\
(12.57)\end{array}$ & $\begin{array}{l}0.936 \\
(1.37)\end{array}$ & (c) & $\begin{array}{l}0.038 \\
(6.97)\end{array}$ & $\begin{array}{l}1.224 \\
(1.60)\end{array}$ \\
\hline Under-education & (c) & $\begin{array}{l}-0.068 \\
(9.67)\end{array}$ & $\begin{array}{l}1.091 \\
(1.46)\end{array}$ & (c) & $\begin{array}{l}-0.040 \\
(6.94)\end{array}$ & $\begin{array}{l}1.130 \\
(1.86)\end{array}$ \\
\hline Experience (Exp) & $\begin{array}{c}0.039 \\
(15.89)\end{array}$ & $\begin{array}{c}0.038 \\
(15.38)\end{array}$ & $\begin{array}{l}20.913 \\
(10.43)\end{array}$ & $\begin{array}{l}0.013 \\
(4.45)\end{array}$ & $\begin{array}{l}0.015 \\
(5.14)\end{array}$ & $\begin{array}{l}23.067 \\
(10.65)\end{array}$ \\
\hline $\operatorname{Exp}^{2} / 100$ & $\begin{array}{l}-0.063 \\
(10.80)\end{array}$ & $\begin{array}{l}-0.065 \\
(10.91)\end{array}$ & $\begin{array}{l}546.176 \\
(466.47)\end{array}$ & $\begin{array}{l}-0.023 \\
(3.87)\end{array}$ & $\begin{array}{l}-0.027 \\
(4.55)\end{array}$ & $\begin{array}{l}645.523 \\
(516.42)\end{array}$ \\
\hline $\begin{array}{l}\text { Logs Weeks } \\
\text { Worked }\end{array}$ & $\begin{array}{c}1.535 \\
(11.73)\end{array}$ & $\begin{array}{c}1.384 \\
(10.71)\end{array}$ & $\begin{array}{l}3.926 \\
(0.06\end{array}$ & $\begin{array}{c}1.653 \\
(11.93)\end{array}$ & $\begin{array}{c}1.495 \\
(10.93)\end{array}$ & $\begin{array}{l}3.921 \\
(0.06)\end{array}$ \\
\hline Married & $\begin{array}{l}0.080 \\
(5.36)\end{array}$ & $\begin{array}{l}0.072 \\
(4.95)\end{array}$ & $\begin{array}{l}0.670 \\
(0.47)\end{array}$ & $\begin{array}{l}0.075 \\
(4.41)\end{array}$ & $\begin{array}{l}0.074 \\
(4.41)\end{array}$ & $\begin{array}{l}0.710 \\
(0.45)\end{array}$ \\
\hline Metropolitan & $\begin{array}{c}0.226 \\
(15.29)\end{array}$ & $\begin{array}{c}0.215 \\
(14.65)\end{array}$ & $\begin{array}{l}0.668 \\
(0.47)\end{array}$ & $\begin{array}{l}0.144 \\
(5.27)\end{array}$ & $\begin{array}{l}0.150 \\
(5.57)\end{array}$ & $\begin{array}{l}0.910 \\
(0.29)\end{array}$ \\
\hline $\begin{array}{l}\text { Fluent in Official } \\
\text { Languages }\end{array}$ & (c) & (c) & (c) & $\begin{array}{l}0.075 \\
(1.38)\end{array}$ & $\begin{array}{l}0.049 \\
(0.92)\end{array}$ & $\begin{array}{l}0.972 \\
(0.17)\end{array}$ \\
\hline Quebec & $\begin{array}{l}-0.203 \\
(9.29)\end{array}$ & $\begin{array}{l}-0.196 \\
(9.08)\end{array}$ & $\begin{array}{l}0.299 \\
(0.46)\end{array}$ & $\begin{array}{l}-0.210 \\
(6.97)\end{array}$ & $\begin{array}{l}-0.021 \\
(7.14)\end{array}$ & $\begin{array}{l}0.110 \\
(0.31)\end{array}$ \\
\hline Ontario & $\begin{array}{l}-0.064 \\
(3.05)\end{array}$ & $\begin{array}{l}-0.056 \\
(2.73)\end{array}$ & $\begin{array}{l}0.390 \\
(0.49)\end{array}$ & $\begin{array}{l}-0.007 \\
(0.36)\end{array}$ & $\begin{array}{l}-0.001 \\
(0.07)\end{array}$ & $\begin{array}{l}0.604 \\
(0.49)\end{array}$ \\
\hline Prairie & $\begin{array}{l}-0.156 \\
(6.71)\end{array}$ & $\begin{array}{l}-0.160 \\
(6.97)\end{array}$ & $\begin{array}{l}0.192 \\
(0.39)\end{array}$ & $\begin{array}{l}-0.126 \\
(4.78)\end{array}$ & $\begin{array}{l}-0.131 \\
(5.05)\end{array}$ & $\begin{array}{l}0.121 \\
(0.33)\end{array}$ \\
\hline $\begin{array}{l}\text { Years since } \\
\text { Migration (YSM) }\end{array}$ & (c) & (c) & (c) & $\begin{array}{c}0.027 \\
(11.76)\end{array}$ & $\begin{array}{c}0.025 \\
(11.16)\end{array}$ & $\begin{array}{l}20.810 \\
(12.71)\end{array}$ \\
\hline $\mathrm{YSM}^{2} / 100$ & (c) & (c) & (c) & $\begin{array}{l}-0.030 \\
(6.75)\end{array}$ & $\begin{array}{l}-0.031 \\
(7.10)\end{array}$ & $\begin{array}{c}594.66 \\
(620.26)\end{array}$ \\
\hline Citizen & (c) & (c) & (c) & $\begin{array}{l}0.131 \\
(6.01)\end{array}$ & $\begin{array}{l}0.129 \\
(6.03)\end{array}$ & $\begin{array}{l}0.814 \\
(0.39)\end{array}$ \\
\hline$\overline{\mathrm{R}}^{2}$ & 0.116 & 0.135 & - & 0.102 & 0.126 & - \\
\hline Sample Size & 19,291 & 19,291 & 19,291 & 18,807 & 18,807 & 18,807 \\
\hline
\end{tabular}

Notes: (a) Heteroscedasticity consistent " $t$ " statistics in parentheses.

(b) Computed using the Realized Matches procedure as the reference level of schooling.

(c) Variable not entered into specification.

Dependent variable: Natural logarithm of earnings in 2000.

Source: 2001 Canadian Census PUMS. 
Table B.3

Implied Payoffs to Schooling, Adjusting for Effects of ORU Variables, Canada, Males

Native-born males

\% Payoff

7.6

Foreign-born males

- no adjustment

a) assuming same earnings effects to reference education as native-born males

b) assuming same earnings effects to reference education and under-education as native-born males

c) assuming same earnings effects to reference education, under-education and over-education as native-born males

d) as for (c) but also same levels of reference education, under-education and over-education within each schooling category as native-born males

e) as for (e) but also assuming same distribution across schooling categories for foreign-born males as for nativeborn males 7.6

Source: Authors' calculations.

Table B.4

Implied Payoffs to Schooling, Adjusting for Effects of ORU Variables, Canada, Females

Native-born females \% Payoff 10.0

Foreign-born females

- no adjustment

a) assuming same earnings effects to reference education as native-born females

b) assuming same earnings effects to reference education and under-education as native-born females

c) assuming same earnings effects to reference education, under-education and over-education as native-born females

d) as for (c) but also same levels of reference education, under-education and over-education within each schooling category as native-born females

e) as for (e) but also assuming same distribution across schooling categories for foreign-born females as for native-born females

Source: Authors' calculations. 
Table B.5

Implied Payoffs to Schooling, Adjusting for Effects of ORU Variables, Canada, Males

Native-born males

\% Payoff

Foreign-born males

7.6

- no adjustment

a) assuming same levels of reference education, undereducation and over-education within each schooling category as native-born males

b) as for (a) but also assuming same earnings effects to reference education, under-education and over-education as native-born males

c) as for (b) but also assuming same distribution across schooling categories for foreign-born males as for nativeborn males

Source: Authors' calculations

Table B.6

Implied Payoffs to Schooling, Adjusting for Effects of ORU Variables, Canada, Females

Native-born females \% Payoff

Foreign-born females 10.0

- no adjustment

a) assuming same levels of reference education, undereducation and over-education within each schooling category as native-born females

b) as for (a) but also assuming same earnings effects to reference education, under-education and over-education as native-born females

c) as for (b) but also assuming same distribution across schooling categories for foreign-born females as for native-born females

Source: Authors' calculations. 
Table B.7

Implied Payoffs to Schooling, Adjusting for Effects of ORU Variables, Comparisons of Native-Born Females and Native-Born Males, Canada

Native-born females

\% Payoff

Native-born males

- no adjustment

a) assuming same earnings effects to reference education as native-born females

b) assuming same earnings effects to reference education and under-education as native-born females

c) assuming same earnings effects to reference education, under-education and over-education as native-born females

d) as for (c) but also same levels of reference education, under-education and over-education within each schooling category as for native-born females

e) as for (e) but also assuming same distribution across schooling categories for native-born males as for nativeborn females

Source: Authors' calculations.

Table B.8

Implied Payoffs to Schooling, Adjusting for Effects of ORU Variables, Comparisons of Foreign Born Females and Foreign Born Males, Canada

Foreign-born females

$\frac{\% \text { Payoff }}{6.8}$

Foreign-born males

- no adjustment

a) assuming same earnings effects to reference education as foreign-born females

b) assuming same earnings effects to reference education and under-education as foreign-born females

c) assuming same earnings effects to reference education, under-education and over-education as foreign-born females

d) as for (c) but also same levels of reference education, under-education and over-education within each schooling category as foreign-born females

e) as for (e) but also assuming same distribution across schooling categories for foreign-born males as for foreign-born females

Source: Authors' calculations. 